\title{
THE ROLE OF DIGITAL TECHNOLOGIES IN THE NEW CODE OF CIVIL PROCEDURE
}

\author{
Noémi Suri \\ Pázmány Péter Catholic University, Faculty of Law and Political Sciences
}

\begin{abstract}
In my essay, I will examine the role played by electronic technologies in the new Code of Civil Procedure. My hypothesis is that despite the sensu stricto text of the law, the new law is built around entirely the use of electronic means of contact to be utilized instead of the traditional, paperbased solutions. The essay will on one hand uncover the overarching structure of the legislation, and on the other hand it will analyze and evaluate the substance and remits of the choice of electronic means of contact. Furthermore, it will uncover the special rules governing communication with experts, and administrative and other authorities as well as between courts. Additionally, it will scrutinize the regulations pertaining to actions taken via electronic means of contact.
\end{abstract}

Keywords: civil procedure, new Code of Civil Procedure, digital technologies, written electronic communication, oral electronic communication, electronic document management, electronic communication networks

\section{INTRODUCTION}

On $22^{\text {st }}$ of November 2016 the Hungarian National Assembly adopted Act CXXX of 2016 on the Code of Civil Procedure, which shall be applied in civil proceedings brought before a court as of $1^{\text {st }}$ of January 2018. The major goal of the codification process during the creation of the new legislation was from the beginning to apply and use the possibilities of new technologies in order to ensure effective, fast and timely closure of civil procedures. ${ }^{1}$

In this essay I explore the roles of electronic technologies with regard to the renewed system of civil procedures in its entirety. In my initial thesis I state that contrary to current legislation the new code constructs a system of rules based on electronic communication rather than a paper-base one. Besides providing an overall picture of the regulatory system, in this essay I also analyse and assess the provisions regarding the rights and the scope of choosing electronic means of communication, the specific rules of electronic communication with experts, courts and public authority bodies and the regulations of electronic submissions.

\section{THE SPIRIT OF LEGISLATION}

While establishing the civil procedural framework for Hungarian jurisdiction the Civil Procedure Main Codification Committee considered dematerialisation appearing in "The concept of the new

1 The concept of the new Code of Civil Procedure (hereinafter referred to as the Concept") adopted by the Hungarian Government on 14 January 2015, 1., p. 18 - 19. http://www.kormany.hu/download/f/ca/30000/20150128\%20Az\%20\% C3\%BAj\%20polg\%C3\%A1ri\%20perrendtart\%C3\%A1s\%20koncepci\%C3\%B3ja.pdf [cited 29. 09. 2018] 
Civil Procedure Code" (hereinafter referred to as the "Concept") adopted by the Hungarian Government on $14^{\text {th }}$ of January 2015, as an asset facilitating the effectiveness of procedures. The Concept accentuates the correct use of information technology solutions: the acceleration of proceedings shall not mean the dismantling of procedural guarantees. ${ }^{2}$ The Concept highlighted the benefits of five aspects of dematerialisation: a) written electronic communication; b) oral electronic communication; c) electronic document management; d) electronic administration; e) electronic archives. ${ }^{3}$

In the draft concept and the study providing the base thereto prepared in the first phase of the codification, the author Professor Viktória Harsági drew the attention to the limitations of the usability of information technology. The professor elaborated on the limitations of the possibilities of modern technology through the comparative analysis of basic principles and arrived at the conclusion that the spread of information technology "may lead to the relative reinterpretation of certain traditionally accepted principles."

After several years of concentrated efforts, work committees that assumed an active role in 2013 and went through a major reorganisation in May 2015, compiled an "Expert proposal" as part of the preparation for codification which stated that infocommunication tools shall be "embedded as an integral part of legislation" . The Expert proposal placed the provisions on electronically lodged submissions among the general rules of submissions. It also suggested the drafting of separate legislation to regulate other issues related to electronic communication.

Pursuant to the new code adopted by the Hungarian National Assembly as the prevailing legislation, the use and adoption of electronic technologies in civil procedures is jointly governed by Act CCXXII of 2015 on the general rules of electronic procedures and trust services (hereinafter referred to as the "e-Procedure Act") and the Code of Civil Procedure. Government Decree 451/2016 should also be mentioned as the implementing regulation of the e-Procedure Act, which defines technically detailed provisions.

At the level of legal sources, the provisions of the e-Procedure Act and the Code of Civil Procedure are applicable both as general and specific rules. The e-Procedure Act constitutes the legal framework for the applicability of electronic technologies and shall be considered governing in the issues not regulated under the Code of Civil Procedure. The e-Procedure Act defines the basic principles of electronic procedures and electronic communication while clarifying primary notions, issues of interpretation, ${ }^{6}$ and sets the rights and obligations of clients bound to or having the right to use electronic communication as well as the responsibilities of authorities granting access to electronic procedures.

The Code of Civil Procedure effective as of $1^{\text {st }}$ of January 2018 outlines the rules of electronic communication primarily and as per its objective in a separate chapter. However, having reviewed the entire system of regulations within the code, both the general part on institutions and the one on special procedures contain rules related to the application of electronic tools.

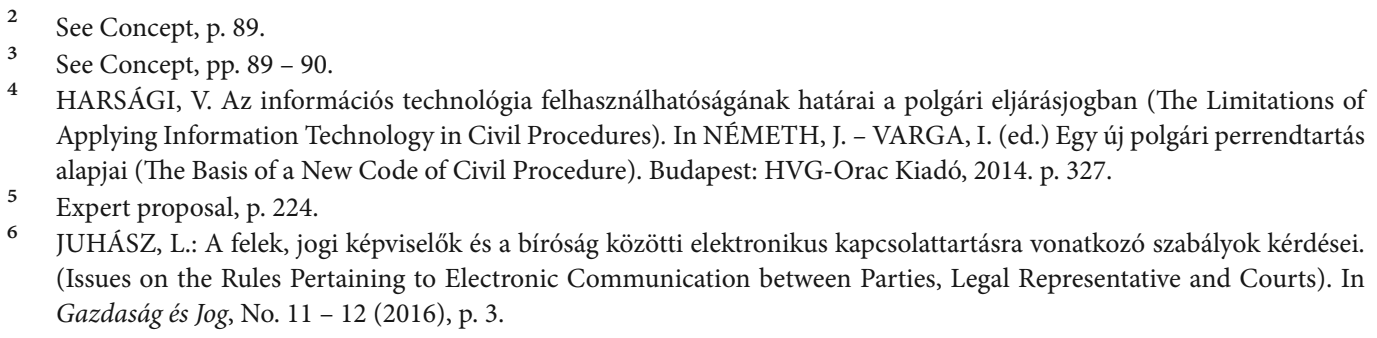

6 JUHÁSZ, L.: A felek, jogi képviselők és a bíróság közötti elektronikus kapcsolattartásra vonatkozó szabályok kérdései. (Issues on the Rules Pertaining to Electronic Communication between Parties, Legal Representative and Courts). In Gazdaság és Jog, No. 11 - 12 (2016), p. 3. 
Therefore, in my opinion, the system of rules defined in the Code of Civil Procedure is multilayered: with regard to electronic communication, law enforcement officials need to comply with the specific procedural rules applicable for electronic communication during specific procedures in combination with the specific rules outlined in Chapter XVI of the Code of Civil Procedure. In any matters not governed by these parts, the provisions of the general sections of the Code of Civil Procedure and the rules of the use of electronic technologies shall be applicable.

\section{ELECTRONIC COMMUNICATION AS A PRIMARY FORM OF COMMUNICATION}

The place of detailed rules for electronic communication within the code and among the special procedures indicates, that the rules of the new Code of Civil Procedure, similarly to the system of rules of the former one, define paper-based communication as the primary mode of communication. According to Bertalan Baranyi's approach the so-called reference rule in Section 604 of the Code of Civil Procedure $^{7}$ also supports this concept. ${ }^{8}$

This taxonomic interpretation is somewhat contradicted by the general rule of legal representation prescribed for legal proceedings, which if reviewed from the aspect of communication establishes electronic communication as a general rule. This approach is further reinforced by the fact that the legislator designated general courts as courts of first instance (where legal representation is obligatory). ${ }^{9}$

The right to electronic procedures is defined by Section $8(1)^{10}$ of the e-Procedure Act, which is further limited in legal proceedings by the right of choosing electronic communication as outlined in Section $605^{11}$ of the Code of Civil Procedure. Parties are entitled to the right of choice regarding electronic communication if they act in person or through representatives not qualifying as legal representatives. Thus it can be stated that the right of choosing electronic communication is only provided for parties in proceedings initiated in front of district courts.

No deadline for defining the mode of contact is prescribed by the Code for Civil Procedure, consequently the party not obliged to use electronic communication may decide to use electronic communication at any stage of the procedure. However, after reporting it, requesting party is bound

7 See Section 604 of the Code of Civil Procedure "[Reference Rule] During electronic communication the provisions of this act shall be applied in harmony with the differences outlined in this chapter."

8 BARANYI, B. Az elektronikus technológiák és eszközök alkalmazása. (The Application of Electronic Technologies and Tools). In VARGA, I. (ed.) A polgári perrendtartás és a kapcsolódó jogszabályok kommentárja. (Commentary on the Hungarian Code of Civil Procedure and Related Legislations). Budapest: HVG-ORAC Kiadó, 2018. p. 2090.

9 See Section 72 (1) of the Code of Civil Procedure: "Legal representation is obligatory in civil proceedings unless stipulated otherwise by law. (2) Unless otherwise defined by law, legal representation is not obligatory for the party lodging the defence in proceedings of district court jurisdictions - including appeal or retrial procedures - and in review procedures pertaining to a lawsuit of district court jurisdiction."

10 Section 8 (1) of the e-Procedure Act: "Lacking any provisions to the contrary in any law or government decree created through original legislative power, clients are entitled to execute their administrative tasks through electronic means and submit their declarations electronically towards an authority that provides for electronic communication."

11 Section 605 of the Code of Civil Procedure "[Optional communication through electronic means] (1) In civil procedures the party not obliged to use electronic communication or its representative not qualified as a legal representative - except for the cases outlined in paragraph (5) - may submit any claims, other submissions and annexes thereto or documents (in this chapter furthermore referred to as "submissions") electronically as by their choice pursuant to the modes outlined in the e-Procedure Act and the implementation regulations thereof. 
by the chosen mode of communication, which is governing for them in proceedings of the first as well as the second instance. The choice of communication through electronic means is dependent on the person not legally obliged to use electronic communication ${ }^{12}$. Legal successors are not bound by this definition of the mode of communication: if legal succession occurs during the procedure, the successor may choose the mode of contact, as long as they are not obliged to use electronic communication. ${ }^{13}$

The new code provides some, albeit limited, grounds for switching from electronic to paperbased communication. The switch shall be requested by the interested party and the reason for the switch together with justification for the changes in party's circumstances shall be indicated to support the claim that electronic communication would place a disproportionate burden on the party from that point on. Such reasons may be: accident, illness, ${ }^{14}$ or the loss of technical capacities due to the failure of computers.

The case may be such, that only one of the parties in a procedure is obliged to use electronic communication, or only one of the parties is willing to adopt it. In such cases the digitalisation of documents and their electronic forwarding to the recipient party is the responsibility of the court. ${ }^{15}$ The court shall digitalise documents received on paper within five working days. The time needed for digitalisation shall be disregarded when considering procedure deadlines. ${ }^{16}$

\section{OBLIGATORY ELECTRONIC COMMUNICATION}

It is the e-Procedure Act, that defines who is obliged to communicate electronically, not the Code of Civil Procedure. ${ }^{17}$ Bertold Baranyi identifies three categories of liable parties: 1) business entities, 2) public entities (including in particular the state, local governments, budgetary bodies, the prosecutor, notaries, public bodies and other public administration authorities), 3) a client through legal representative. ${ }^{18}$

The party, or the representative thereof, who, by its own right outlined in Section 605 of the Code of Civil Procedure, is not obliged to use electronic communication, but chooses to do so, after

12 VITVINDICS, M. Az elektronikus technológiák és eszközök alkalmazása. (The Application of Electronic Technologies and Tools). In WOPERA, ZS. (ed.) A polgári perrendtartásról szóló 2016. évi CXXX. törvény magyarázata. (The Interpretation of Act CXXX of 2016 on the Code of Civil Procedure). Budapest: Wolters Kluwer Kft., 2017. p. 684.

13 See Section 607 of the Code of Civil Procedure: "The predecessor's choice of electronic communication or a completed switch to the paper-based delivery of documents to predecessor shall not be binding for a successor without a legal representative."

14 BARANYI, ibid, p. 2096.

15 See Section 606 (2): "No separate court order is necessary in case of a switch to paper-based communication. The court shall notify any parties or their representatives not qualifying as legal representatives about the rejection of a request for switching to a paper-based format."

16 Section 613 (2) of the Code of Civil Procedure.

17 Section 9 (1) of the e-Procedure Act: "Unless a law based on an internationally binding contractual obligation or an international contract defines provisions to the contrary, the following parties are obliged to apply electronic communication in cases pursuant to Section 2 (1): a) party proceeding as a client, and is either aa) a business entity, ab) a state, ac) a local government, ad) a budgetary body, ae) a prosecutor, af) a notary, ag) public body, or ah) any other public administration authority not named under points ac) - ag), b) legal representatives of clients.

18 BARANYI, ibid, pp. $2097-2098$. 
reporting such choice shall use electronic means of contact towards the court during proceedings (even legal remedy cases), and the court shall send any documents to party electronically. ${ }^{19}$

The Code of Civil Procedure defines specific provisions pertaining to communication with experts, the courts, any public authority bodies or other authorities. Electronic communication is obligatory between courts or when contacting other authorities except for cases where the presentation of a paper-based document becomes necessary during an evidence procedure. Rules of communication with experts may depend on whether the expert is bound for electronic communication by the e-Procedure Act or not.

\section{THE POSSIBILITY OF USING ELECTRONIC COMMUNICATION NETWORKS}

The new code, just as well as the old one, ensures the possibility of using electronic communication networks during legal proceedings too.

A new rule in civil procedures states that electronic communication networks (for the purposes of audio and video connections) may not only be used during court hearings but at inspections as well. It may be applied upon request by parties, but the court has the right to order it too. The code defines three cases where ordering electronic communication is possible. In my opinion, all three cases aim at enforcing each and every basic principle within the code: a) the rule, pursuant to which the use of electronic communication networks may be ordered in cases where their application seems suitable to accelerate the legal process, may be considered an instrument to ensure the principle of procedure concentration and efficiency, b) ensuring access to justice and legal assistance is the purpose of the provision prescribing the potential order of electronic communication in cases where conducting a hearing or an inspection would otherwise be difficult or entail disproportionately large extra costs, and c) witness protection as the third category of cases enforcing the requirement of data privacy (protection of personal data) as well as the protection of personal rights.

During a hearing or inspection through audio or video connection two main principles arise, namely the principle of immediacy and the capability of ensuring the adversarial principle of procedures. The purpose of the rule is to ensure the practical application of these two main principles by prescribing that electronic communication networks shall only be applied, if the communication tool is capable of transmitting the image and the sound simultaneously thus providing direct connection between separate locations of the procedure.

The new code accurately defines the requirements for the location of hearings through electronic communication networks and the mode of such hearings. It stipulates that the principle of publicity shall be ensured at the location of the hearing, therefore at such sites connected through electronic means only the person to be heard, the owner of the subject of inspection and the technical staff ensuring the electronic connection shall be present.

So-called secret hearings may also be requested in procedures applying electronic communication networks. In such cases the court may order the distortion of any characteristics by which a witness could be identified, or a mode of hearing which would disallow for the identity or place of residences of the witness to be recognised.

19 VITVINDICS, ibid, p. 682 
When using electronic communication networks, special rules shall be applied for the preparation of minutes as well. The minutes shall include the conditions of the personal hearing and the identification of the people present at the separate location.

\section{SUMMARY}

The review of current rules and regulations reveal that the new code contains more progressive and considerable rules for electronic communication. It is a positive development that the legislator provides opportunities for the use of electronic communication networks during witness hearings as well as inspections. Nonetheless, the multiple layers of rules and regulations do not lift the burden from law enforcement officials during both obligatory and optional electronic communication.

\section{Bibliography:}

BARANYI, B. Az elektronikus technológiák és eszközök alkalmazása. (The Application of Electronic Technologies and Tools). In VARGA, I. (ed.) A polgári perrendtartás és a kapcsolódó jogszabályok kommentárja. (Commentary on the Hungarian Code of Civil Procedure and Related Legislations). Budapest: HVG-ORAC Kiadó, 2018.

HARSÁGI, V. Az információs technológia felhasználhatóságának határai a polgári eljárásjogban (The Limitations of Applying Information Technology in Civil Procedures). In NÉMETH, J. - VARGA, I. (ed.) Egy új polgári perrendtartás alapjai (The Basis of a New Code of Civil Procedure). Budapest: HVG-Orac Kiadó, 2014.

JUHÁSZ, L.: A felek, jogi képviselők és a bíróság közötti elektronikus kapcsolattartásra vonatkozó szabályok kérdései. (Issues on the Rules Pertaining to Electronic Communication between Parties, Legal Representative and Courts). In Gazdaság és Jog, No. 11 - 12 (2016).

VITVINDICS, M. Az elektronikus technológiák és eszközök alkalmazása. (The Application of Electronic Technologies and Tools). In WOPERA, ZS. (ed.) A polgári perrendtartásról szóló 2016. évi CXXX. törvény magyarázata. (The Interpretation of Act CXXX of 2016 on the Code of Civil Procedure). Budapest: Wolters Kluwer Kft., 2017.

\section{Contact information:}

Dr. Noémi Suri

suri.noemi@jak.ppke.hu

Pázmány Péter Catholic University

Faculty of Law and Political Sciences

Szentkirályi u. 28-30

1088 Budapest

Hungary 